\title{
Affirmative Action: Equal Opportunity For Women in Library Management
}

\begin{abstract}
Women can achieve equal opportunity in library management through Affirmative Action Committees. Several steps are suggested: the determination of present status; assessment of library policies affecting hiring, parental leave and promotion; some strategies to attain managerial positions.
\end{abstract}

The only way for a woman, as for a man, to find herself, to know herself as a person, is by creative work of her own. There is no other way. But a job, any job, is not the answer-in fact, it can be part of the trap. Women who do not look for jobs equal to their actual capacity, who do not let themselves develop the lifetime interests and goals which require serious education and training ... are walking, almost as surely as the ones who stay inside the housewife trap, to a nonexistent future. If a job is to be the way out of the trap for a woman, it must be a job that she can take seriously as part of a life plan, work in which she can grow as part of society. ${ }^{1}$

L L work in which they may find themselves, but because of sex discrimination, these positions are more frequently offered to men than women. For example, 80 percent of librarians are women, but 90 percent of library administrators are men. Because evidence of widespread discrimination in library management

At the time this article was written Ms. De Fichy was a student at Syracuse University, School of Library Science, New York. is well documented (Anita Schiller has written several articles on the subject), I propose to limit my discussion to the actions which can, and in most cases, should be taken to ensure women a greater variety of professional opportunities.

Although the American Library Association has initiated policies pertaining to equal opportunity for women (see recent issues of American Libraries), it will in most cases be up to individuals to launch affirmative action programs within their own libraries. Once the library staff and the community are cognizant of the fact that women are being discriminated against, it is unlikely that the practice will be endorsed as complacently or routinely as it is now. While men increasingly admit that sex discrimination does exist, greater public awareness is requisite before women in the profession will be able to demand better treatment and opportunities.

While most women librarians are aware of discriminatory hiring and promotion practices, they need to be made aware of their abilities and potential. "Women's negative self-image is a major barrier to improvement in their status. The view of themselves as inferior and lacking in intellectual and other skills necessary for success prevents 
many women from trying and severely handicaps those who do. . . . Left to themselves, women will self-select into occupations consistent with their selfimage, thus leaving unchallenged traditionally masculine fields." ${ }^{2}$ (The point is not that "men's work" is inherently more fulfilling or more creative than "women's work," but rather that "men's work" has been given a higher social value and is therefore more highly paid. A woman should have the same opportunities open to her.) Much of the responsibility for encouraging women to develop their potential abilities should be assumed by those women who have succeeded in attaining high-level positions. Most people, with the exception of the most highly motivated, need someone to look to for inspiration and guidance; forward-looking women will benefit substantially from the support of women managers in the library.

Women interested in developing their potential should take advantage of any opportunity to expand their interests and sharpen their skills. By returning to school, even on a part-time basis, they can derive valuable insights and personal satisfaction. Moreover, they can set an example for fellow workers and can demonstrate to supervisors that women do have motivation and interest. ${ }^{3}$

Given encouragement and support, women will be in a better position to influence the development of an affirmative action program. While strategies will vary within different institutions, those which may be useful include:

1. Reporting on discrimination as brought out in library literature.

2. Discussing why it is important to end sex discrimination in libraries.

3. Exploring legal aspects.

4. Speaking about myths pertaining to women as workers.

5. Focusing on ALA policies designed to end sex discrimination.

Such efforts may occasion the establish- ment of the Affirmative Action Committee to be charged primarily with examining the status of women within the library and making recommendations for affirmative action.

The work of the individual must not end here, however. Remedying the situation in one department or in one library will not end discrimination practiced elsewhere in the community. Women should endorse local and national organizations aiming to effect equal employment opportunities for women-e.g. the National Organization of Women and the Professional Women's Caucus. Helen S. Astin suggests that there should be "new tax laws that would permit the professional and any working woman to deduct expenses she incurs by employing domestic assistants" (this would include child-care costs). ${ }^{4}$ Women should actively campaign (e.g. writing letters to congressmen and local newspapers) for passage of such laws. By supporting the establishment of improved child-care centers, women can do much to enhance their employability. If discriminatory practices are not abandoned in libraries, librarians can file a complaint with the Equal Employment Opportunities Commission (EEOC). The Equal Employment Opportunity Act of 1972 (PL92-261) now covers all academic and school libraries and most public libraries (check with any Regional Office of EEOC for further details). Librarians who feel they are victims of sex discrimination should publicize their complaints both in the library and in the community at large.

In order to recommend any changes in policy, the Affirmative Action Committee must first determine the present status of women working in the library. This can be deduced from the answers to questions including:

1. What percentage of the library's total personnel are women?

2. What percentage of the administrative staff are women? 
3. How many women have advanced at approximately the same rate as their male peers?

4. How did women managers reach their present position?

5. How was their potential recognized?

6. What is the average length of service of male employees? of female employees?

7. On the average, do women managers stay with the library as long as their male counterparts?

8. Is there an earnings gap between men and women in positions of equal responsibility?5

In determining the answers to these questions, it will be necessary to scrutinize the positions which women currently hold:

1. Are they dead-end positions, or do they offer advancement opportunity?

2. Are the managerial positions "temporary," and if so, how long have women held these positions?

3. What are the actual responsibilities of women holding high level positions? Are they doing more than is implied by their titles and/or salaries? ${ }^{6}$

If possible, the reasons why women employees have left the library should also be investigated. Did they leave because they were offered more responsibility or a higher salary elsewhere?

The Affirmative Action Committee's next step should be to assess the library's policies relating to recruitment and hiring, parental leave, and promotion. Questions that should be asked include:

\section{Recruitment and hiring}

1. Are women being sought out for high level positions?

2. Do recruiters unconsciously or consciously discourage women applicants for these positions?

3. Are questions asked concerning marital status, number of children, etc.?

4. What factors enter into the final decision?

\section{Parental leave}

1. Are women allowed to take leave for childbirth without losing status or seniority?

2. Do they receive remuneration during this period??

\section{Promotion}

1. Do women have open to them the same potential career paths as men?

2. Do we have a system for identifying qualified women?

3. Are annual performance appraisals sexually unbiased?

4. Are women (as well as men) offered the chance to prove their potential in management training and development seminars, job rotation, etc.?

5. Is there a procedure by which a woman can appeal to her supervisor if she believes she is not being promoted rapidly enough?8

6. Is the decision for promotion of men and women based upon equal standards?

During the committee's initial investigation, attitudes of both men and women within the organization must be researched. This is a more difficult area to investigate than those already discussed, and it may be necessary to call in professionals in order to gather the information. It is important both to identify the attitudes and to determine how strongly they are held.

Finally, the Affirmative Action Committee must ensure that they have the full support of top-management. Without adequate resources and authority (which only top-management can give), implementation of the committee's plans cannot be effective in producing lasting change. Data that has been collected pertaining to personnel, policies, and attitudes should be used to gain the necessary management support. It may also be helpful for the committee to prove that affirmative actions will benefit everyone. Dennis Slevin maintains that once top-management support is obtained, "a clear statement of policy" 
should be distributed, thus leaving no doubts as to the commitment and intentions of the administration. ${ }^{9}$

The next step of the Affirmative Action Committee should be to suggest strategies which will increase the percentage of women in management, effect anti-discrimination policies, and improve the attitudes of workers toward women managers.

One reason why women have rarely attained managerial positions can be attributed to their family-oriented responsibilities. The relatively low salary of a woman librarian (as compared to that earned by men and women in most other professions) often necessitates a greater dependence on her husband's higher-paying job. In such cases, her choice of job locations becomes dependent upon her husband's. If she is a mother, she is usually given the entire responsibility of caring for the children. The major obstacle confronting the mother who wishes to work is the difficulty and expense involved in finding child-care. The Affirmative Action Committee must strive to reduce the problems of working mothers. Proposals to further this objective include:

1. Raise the salaries of all library employees to a level equaling those of "male" occupations with commensurate requirements.

2. Close the earnings gap between men and women with similar qualifications and education in positions of equal responsibility.

3. Provide child-care facilities for children of both male and female employees.

4. Guarantee that a woman can return to her former job after maternity leave (within a specified period of time) without loss of seniority or status. ${ }^{10}$

5. Provide more job opportunities for women with children; create parttime or temporary positions, and make work schedules more flexible. ${ }^{11}$
Many women feel that the provision of child-care facilities is fundamentally requisite to improved job opportunities. This may be too difficult and expensive for a library to undertake single-handedly, but given the cooperation of the parent organization (the university, company, etc.) and/or other local institutions, it can be easily accomplished. Alice Rossi points out that universities are exceptionally well-equipped for the establishment of a child-care center. Specialists in psychology, education, and human development would help make the center beneficial to the child as well as the parent. ${ }^{12}$ Anundsen and Gould maintain that the greatest attribute of existing centers is that "they are for the children of both male and female employees. Just the recognition that children belong to fathers as well as mothers-that day care centers are for families, not simply for women-is an important step in freeing women to take on larger responsibilities outside the home ... day care centers reap benefits in terms of morale, lower absenteeism, and less employee turnover."13

Upon reviewing the library's hiring and promotion policies, it will not be difficult for the Affirmative Action Committee to decide what changes should be made. It will generally recommend that:

1. Any qualified candidate be considered for all vacancies.

2. Interviews and decisions focus on professional competence rather than on marital status and/or sex.

3. Employers be taught how to recognize women with managerial ability. ${ }^{14}$

Once a library decides to change its hiring and promotion policies to end sex discrimination, it must take steps to compensate for discrimination practiced in the past. Women who have not been promoted to better job positions despite their having the equivalent qualifications and experience of men who have been promoted should be advanced to 
the higher level position or status for which they are qualified as quickly as possible. High level vacancies should be filled with women (except when no woman with adequate qualifications or potential is available) until the number of women managers is proportionate to the total number of women librarians employed in the library. The AAPW Committee at Berkeley recommends that "an optimum recruitment period for job openings during which the Personnel Office searches for acceptable women applicants should be established. A position may not be filled by a man until this time period has elapsed."15 If a man is hired, this selection should be justified in writing to the Affirmative Action Committee.

Many library administrators will resent having to hire a woman when they feel that a better qualified man is available. It is necessary to remind these individuals that one reason why men are commonly held to be better qualified is precisely because so few women have had the opportunity to demonstrate and develop their managerial abilities; it is therefore imperative that steps be taken to train women managers:

1. All employees should receive ongoing training in all library operations, thus insuring everyone equal opportunity to develop the skills necessary for advancement.

2. All employees should be encouraged to take management courses offered outside the library.

3. A plan should be devised whereby employees interested in advancement can rotate positions.

4. Men and women should be represented in proportion to their numbers in the library on all library committees and problem-oriented work teams.

5. "Develop promising women, who are not yet available for full-time management, with assignments of overflow management problems that presently overburden the full- time staff, but are not yet sufficiently accumulated to necessitate a new full-time position." 16

In order to make these changes as easy as possible, if will be necessary to develop improved attitudes among the staff. While the establishment of the Affirmative Action Committee may have eliminated certain ill-feelings, it may have also reinforced others. Attitudechange devices which may prove helpful include:

1. Sensitivity training and role playing, centering on the problems women face in their employment.

2. Use of different media to document the managerial potentials of women and expose myths relating to women workers.

3. Group discussions to determine favorable and realistic ways in which women may advance to higher levels of management. ${ }^{17}$

To maintain good attitudes, insure that women managers are never isolated from male employees. Both sexes should continually be involved in work in which they can interact as equals. It is most important that male supervisors have no doubts regarding a woman's capabilities; they should neither expect the woman to know everything, nor expect that they themselves will have to do much of the work. "By and large, people perform according to what is expected of them. If you expect little from your woman manager, she will produce accordingly, unless she is unusually highly motivated. Do expect your female managers to produce as much and as well as your male ones; give them help in areas where they need help (as you would with men) and encourage them with promotions and pay increases and all the accoutrements of prestige, but keep them aware that they must demonstrate their capability."18

To guarantee that equal opportunity for women becomes a reality within the library, the Affirmative Action Commit- 
tee must continue to provide advice and information to library administrators. The committee must appraise periodically the status of women employees, reporting its findings to library administrators. Of course, a library administration, once sensitized to the problem, should provide its own periodic progress reports to the staff. It is equally important that employees feel that they can bring any relevant grievances to the committee. The committee should also help recently-promoted women with any problems resulting from supervisors' or subordinates' attitudes.

It is hoped that an equal opportunity library will influence employment practices within the community at large. Libraries can work toward this goal by publicizing their affirmative action policies and by making the same efforts recommended to individual women. ALA recommends that individual libraries request their library suppliers to adopt similar employment policies. If the library or its parent organization has started a day-care center, it should advise and inform other groups within the community who are trying to do the same. By making available a variety of materials and current bibliographies pertaining to women's history, rights, and status, the library offers tools which may help to change existing social attitudes.

It is important to remember that the prevailing attitudes of men and women rarely originate in their place of employment; they are usually fostered much earlier in life by parents, teachers, counselors, etc. Although a few individuals or a few libraries are admittedly incapable of resocializing the entire American society, they can prod the parent institution, library schools, and ALA into taking stock of the issues. Clarenbach suggests steps to be recommended by affirmative action programs within continuing education:
1. Take affirmative action to promote the employment of women to all positions throughout the institution.

2. Make every effort to incorporate women's studies courses within the various disciplines.

3. Counsel the counselors and train the trainers to help them break through the static concepts of "women's fields" and "women's levels of responsibility."19

Library schools have a dual role to play in affirmative action, the first being to offer a program of study which encourages women to take a more active role in the field of librarianship. "Rather than furthering the prevalent myth that women cannot be successful administrators, graduate schools should try to attract female candidates who can fill leadership positions. Instead of discouraging women in light of their career limitations, library schools should innovate in reducing these restrictions." Secondly, library schools can help women who want to return to work. For example, they can keep librarians who have taken parental leave informed about professional concerns and developments. ALA could also function in this capacity. Courses could be offered to help librarians who have taken extended leaves renew their skills before returning to work. ${ }^{20}$

In addition to offering more women a chance to develop to their full potential, the proposed actions will reap other benefits. Decisions will incorporate not only the male point of view, but also the female: "the encouragement of the natural complement of men and women in business can result in a highly productive mutuality. . . . The presence of women on management teams adds a new dimension, a new perspective."21 Women new to the library profession will see that there is opportunity for advancement, and this will have a positive effect on their morale and goals, and for 
women already employed in the library system, this opportunity for personal growth and status will act as an incentive, making their jobs more flexible and more meaningful. Throughout the library, there will be better utilization of the resources of both men and women. The attitudes of all staff are certain to improve, and it is to be hoped that these will rub off on other members of society. Children will receive better care in improved day-care facilities. Most important of all, affirmative actions will ultimately improve human relations among people representing all strata of society.

\section{REFERENCES}

1. Betty Friedan, The Feminine Mystique (New York: Norton, 1963), p. 344-45.

2. John DeLamater and Linda S. Fidell, "On the Status of Women," American Behavioral Scientist 15:170 (Nov./Dec. 1971).

3. "WOW: A Model for Encouraging Women's Potential; An Interview with Mary Janney, Jane Fleming and Christine Nelson," AAUW Journal 63:71 (Jan. 1970). This point is made by Fleming in a discussion concerning ways women can improve their status in hiring and wages.

4. Helen S. Astin, The Woman Doctorate in America (New York: Russell Sage Foundation, 1970) p. 50.

5. Charles D. Orth, III and Frederick Jacobs, "Women in Management: Pattern for Change," Harvard Business Review 49: 142-3 (July/Aug. 1971). Questions suggested in this article refer in general to business organizations and have been adapted here $(\# 1-8)$ to refer specifically to libraries.

6. Orth and Jacobs, p. 143. Questions \#1-3 have been adapted as previously stated.

7. Questions \#1 and 2 have been adapted from recommendations discussed at length in: Library Affirmative Action Program for Women Committee, "A Report on the Status of Women Employed in the Library of the University of California, Berkeley, with Recommendations for Affirmative Action," (Dec. 1971), p. 38. Hereafter cited as AAPWC.

8. Dennis P. Slevin, "What Companies Are
Doing About Women's Job Equality," Personnel 8:16 (July/Aug. 1971).

9. Slevin, p. 13-14.

10. AAPWC, p. 39.

11. This proposal is dealt with in more detail in: Janet Freedman, "The Liberated Librarian?" Library Journal 95:1711 (May 1, 1970).

12. Alice S. Rossi, "Equality Between the Sexes: An Immodest Proposal," Daedalus 93:632-3 (Spring 1964).

13. Kristin Anundsen and Karolyn Gould, "The Rise of Womanagement," Innovation 24:18 (Sept. 1971).

14. Bird McCord, "Identifying and Developing Women for Management Positions," Training and Development Journal 25:4 (Nov. 1971). McCord provides a kind of checklist by which employers can identify managerial potential in female employees.

15. AAPWC, p. 31.

16. Estill H. Buchanan, "Women in Management," Personnel Administration 32:25 (Sept./Oct. 1969).

17. All three suggestions are given in Slevin, p. 17.

18. Anundsen and Gould, p. 20.

19. Kathryn F. Clarenbach, "Can Continuing Education Adapt?" AAUW Journal 63:65 (Jan. 1970).

20. The suggestions in this paragraph are among those addressed to library schools in Freedman, p. 1711.

21. Anundsen and Gould, p. 21-2. 